\title{
INVITATION TO EXPLANATION OF VOLUNTARY TAX COMPLIANCE
}

\author{
Müge Seda ATEŞ ${ }^{1}$
}

\begin{abstract}
Some disagreements and differences of opinion may arise between taxpayers and tax administration due to taxation process or practices. A peaceful resolution of these disputes by the parties of taxation ensures the administration to gain the tax claims as soon as possible; additionally, it brings some advantages for the taxpayers and particularly it plays a vital role in ensuring voluntary tax compliance. "Invitation to explanation", which is one of the regulations for the resolution of disputes at administrative level, provides an opportunity for enhancing the voluntary tax compliance, which is defined as on time and in full meeting of the taxational liabilities by the taxpayers. With this implementation, which is resolved at the $370^{\text {th }}$ article of the Tax Procedure Law, an opportunity is given to the taxpayers, who caused tax losses according to the preliminary detections applied by the competent authority demonstrating indications about tax loss, to make explanation before facing a criminal action, provided that tax audit or fixation transactions are not started and no notifications are made until the detection date. With this implementation, it is aimed at providing a decrease and a resolution of the disagreements between the parties of taxation at administrative process, ensuring a rapid and efficient taxation process, enabling the participation of the taxpayers in resolution of disagreements, and thus increasing the voluntary tax compliance.

In this study, the implementation of invitation to explanation, which is one of the administrative resolution methods, will be examined; firstly, invitation to explanation notion and its application in Turkish tax system will be clarified, and subsequently some assessments will be made about the implementations of invitation to explanation within the framework of the voluntary tax compliance.
\end{abstract}

Keywords: Tax Dispute, Administrative Solution Way, Invitation to Explanation, Voluntary Tax Compliance

JEL Code: H29, K34

\section{Introduction}

Taxation refers to a bilateral relationship, and time to time legal disputes may arise between the taxpayer and the tax administration regarding tax obligation. These disputes, which are referred to as tax disputes, are being tried to be resolved through administrative (peaceful) or judicial remedies.

One of the administrative remedies, such as regret and correction, correction of mistakes, penalty discount, compromise, which refers to the elimination of the disputes in the administrative stage, without resorting to the judicial authorities for tax is the invitation to explanation. The practice of invitation to explanation is a new type of implementation in terms of Turkish Tax Law, which gives the taxpayer the opportunity to explain the situation it is in, and is based on finding a solution with voluntary compliance of the taxpayer, during the process of identifying the transactions that are causing tax loss based on the signs detected by the competent authorities prior to tax audit. This practice is prescribed in the Article 22 of the Law on Amendment of Several Laws For Improving the Investment Climate and the Abolished Article 370 of the Tax Procedure Law No. 213.

1 Res. Asst., İnönü University, seda.ates@inonu.edu.tr 
In this study, it is aimed to examine the institution of invitation to explanation within the context of voluntary tax compliance. In this context, at first, the concept of invitation to explanation will be studied that is among the administrative remedies, subsequently, the institution of invitation to explanation will be analyzed in light of this information and within the scope of voluntary tax compliance.

\section{The Concept of Invitation to Explanation}

While "explanation" means explaining something, "invitation to explanation" means demanding explanation from the taxpayer in order to determine correctness of the signs of tax loss caused by the taxpayer (Bozdoğan \& Çataloluk, 2018: 43). In other words, invitation to explanation is the demand for explanation from the taxpayer by the competent authorities, in case that these authorities determine external traces of possible tax loss (Buyrukoğlu \& Toparlak, 2018: 58).

The concept of invitation to explanation entered into force with the Law No. 6728 published in the Official Gazette dated 09.08.2016 and numbered 29796, and has taken its place as a new administrative solution in the Turkish tax system with the regulation of the abolished Article 370 of the Tax Procedure Law No. 213 (Oktar, 2018: 425). According to the article 370 of the Tax Procedure Law, the taxpayers can only be invited to explanation if several conditions are fulfilled, such as, competent authorities have reached preliminary results that there is a tax loss; tax audit has not yet started; the case has not been sent to the valuation commission; no denouncement is made until the date of determination; in case there is a possibility of forged documents and documents with misleading contents, the amount for every document is not more that the determined level; no tax loss is caused as a result of tax evasion (Şenyüz et al., 2018: 292). If all these conditions are met, "The Explanation Evaluation Commission" sends the taxpayer a written invitation to explanation. Taxpayers are obliged to provide a written explanation within 15 days from the date of the notification. Those, who do not provide a written explanation to the relevant commission within this period, will not be allowed to benefit from the institution of invitation to explanation (Deloitte, 2017: 2).

As a result of the assessments with this institution, those taxpayers, who didn't cause tax loss won't be subject to tax audit or sent to valuation. And in cases of tax loss, taxpayers are protected from heavier sanctions by implementing discounted penalties under certain circumstances (the penalty for tax loss will be calculated as the $20 \%$ of the tax loss, in other words, the penalty for tax loss will be paid with $80 \%$ discount) (Doğan ve Kabayel, 2018: 59). In doing so, it is aimed to make tax audits more effective and efficient, to prevent unnecessary audit and valuation processes, to prevent taxpayers from facing unfair and unnecessary processes, to reduce disputes and to ensure a faster and more efficient taxation process, to ensure the participation of taxpayers in the dispute resolution process and to increase voluntary tax compliance (Özmen, 2018: 73).

\section{Invitation to Explanation within the Scope of Voluntary Tax Compliance}

Voluntary tax compliance is defined as "the degree that taxpayers act in compliance to tax laws", and implies timely and complete fulfillment of tax liabilities by taxpayers (Şentürk, 2014: 131). Many other factors, such as income level and tax rates, audit possibilities, previous audits and tax penalties, moral and social dynamics, social and demographic factors, tax attitudes, subjective tax information and participation, the attitude of the tax administration, the complexity of 
the tax system and tax amnesty can affect voluntary tax compliance (Kahriman, 2016: 231). However, it is difficult to determine which of the factors are more effective on tax compliance.

In order to ensure voluntary tax compliance, in addition to the taxpayers' obligations, such as correct declaration of taxable income, timely declaration of taxes, correct calculation of due taxes and payment of taxes, it is also important that the respective authorities implement practices for easing fulfillment of these obligations. (Manhire, 2015: 12). In this framework, invitation to explanation, which has been implemented starting with Article 370 of the Tax Procedure Law and is a new solution to the disputes between tax administration and taxpayers, became an important institution aiming at getting the taxpayers to more actively contribute to the clarification of events within the framework of democracy and thus to increase the voluntary tax compliance. As a matter of fact, Article 1 of the Tax Procedure Law General Communique No. 482 states that "this regulation aims to reduce the disputes between the administration and taxpayer, the administration to devote its time to more efficient and productive areas, the taxpayers to more actively contribute to the determination of events' real nature, and thus to increase voluntary tax compliance", and thereby underlines the importance of the invitation to explanation institution with regard to voluntary tax compliance. This institution, which aims to transfer the taxpayer's participation in the process and its opinions on the subject within the principle of trust mostly in the Anglo-Saxon legal systems, also contributes to the development of democracy in taxation (Bayraklı \& Hatipoğlu, 2018: 564).

The institution of invitation to explanation, which is designed as a solution for the taxpayers, for whom the tax audit has not yet begun or whose case has not been sent to the valuation commission, and the right to explain given to the taxpayer could make the taxpayer more willing to fulfill its tax duty. As a matter of fact, in case that competent authorities realize in advance that there are signs of tax loss, instead of immediately issuing penalties to the taxpayers who seems to be causing this tax loss, the administration would listen to the taxpayers (Biyan, 2016: 47). The environment of cooperation and trust created between the taxpayers and the administration will increase tax awareness of the taxpayers and voluntary tax compliance. However, the taxpayers, who regularly pay their taxes and fulfill their other obligations related to tax in a timely and complete manner, will decrease their voluntary compliance, their trust in the administration will be shaken and may start to avoid tax payments after obtaining sufficient information about the subject (Bayraklı \& Hatipoğlu, 2018: 580). In this way, while the state is trying to regain the taxpayers, who are not fully aware of tax purposes in order to increase voluntary compliance, it will gradually encourage the taxpayers, who have been fully paying their taxes, to escape from their tax payments. From the tax awareness perspective, although the practice of invitation to explanation may increase the willingness of taxpayers for fulfilling their tax duty, it will on the other hand decrease the voluntary compliance of the taxpayers, who are already paying their taxes completely and in time, and will also shake their trust in the administration.

\section{Conclusion}

The invitation to explanation, which is a peaceful solution for the settlement of the disputes between the taxpayer and the tax administration, is a new application with regard to the Turkish Tax Law, and has important implications on both the administration and the taxpayers. The institution of invitation to explanation enables the tax administration to receive the tax payments as soon as possible and decreases its disputes with the taxpayers, as well as provides a fast and effective taxing process. From the taxpayers perspective, it provides several advantages such as 
preventing unnecessary audits and valuation procedures, and thus preventing the taxpayer from facing unfair and unnecessary procedures, enabling the taxpayers to contribute more actively to the determination of the real nature of events in regard to the democratic state principle, and thus increasing the voluntary tax compliance.

The institution of invitation to explanation prescribed in Article 370 of Tax Procedure Law is a regulation that saves the taxpayer from tax audit and penalty, and increases the voluntary tax compliance, which is defined as enabling the taxpayer to fulfill its tax liabilities on time and in a complete manner. This institution is more important especially in the tax systems, which are based on the principle of declaration, and plays an important role in incorporating the taxpayer into the tax system and increasing the tax compliance. Although, offering the taxpayer the right to explain itself and increasing the cooperation between the taxpayer and the administration contributes to strengthening of tax awareness, this may decrease the voluntary tax compliance of the taxpayers, who regularly pay their taxes, and weaken their trust in the administration.

\section{References}

Bayraklı, H. \& Hatipoğlu, M. (2018). "İzaha Davet ve İzah Üzerine Yapılacak İşlemlerin Davaya Konu Olması”, Inönü Üniversitesi Hukuk Fakültesi Dergisi, Cilt: 9, Sayı: 2, 2018, ss. 561-592.

Biyan, Ö. (2016). “Idari Aşamada Yeni Bir Çözüm Yolu: İzaha Davet”, Bilanço Dergisi, Sayı: 162, SS. 46-49.

Bozdoğan, D. \& Çataloluk, C. (2018), "Vergi Usul Kanununda Yer Alan İzaha Davet Kurumunun Değerlendirilmesi ve Öneriler", El Ruha 2. Uluslararası Sosyal Bilimler Kongresi, 2018, ss. 42-55.

Buyrukoğlu, S. \& Toparlak E. (2018), "Avantaj ve Dezavantajlarıyla İzaha Davet Müessesesi”, Optimum Ekonomi ve Yönetim Bilimleri Dergisi, Cilt: 5, Sayı: 1, ss. 57-68.

Deloitte. (2017). "Vergi Sirküleri (No: 2017/87)", http://www.verginet.net/Sirkuler/ 2017yili87.pdf, (18.01.2019).

Doğan, A. \& Kabayel, M. (2018). Vergi Hukukunda İzaha Davet Uygulaması, http://vergiraporu. com.tr, (02.02.2019).

Gelir İdaresi Başkanlığı. (2016). "Vergi Usul Kanunu Genel Tebliği (Sıra No: 482)”, http://www.gib. gov.tr/sites/default/files/fileadmin/user_upload/Tebligler/Taslaklar/serno482_VUKTeb_ Taslak.pdf, (12.01.2019).

Kahriman, H. (2016). “Vergiye Gönüllü Uyum Çerçevesinde Türkiye'de Gelir İdaresinin Organizasyon Yapısı Üzerine Bir Değerlendirme", Ekonomik ve Sosyal Araşttrmalar Dergisi, Cilt: 12, Sayı: 1, ss. 229-250.

Manhire, J. (2015). "What Does Voluntary Tax Compliance Mean? A Government Perspective", University of Pennsylvania Law Review Online, 164 (11), ss. 11-17.

Oktar, A. (2018). Vergi Hukuku, 13. Baskı, İstanbul, Türkmen Kitabevi. 
Özmen, İ. (2018). "Vergi Usul Kanunu'nda İzaha Davet: 370 inci Madde Mükelleflere Yeni Bir Fırsat Mı?”, Selçuk Üniversitesi Hukuk Fakültesi Dergisi, Cilt: 26, Sayı: 1, ss. 63-85.

Şentürk, S. (2014), "Vergiye Gönüllü Uyum Sağlanmasında Fayda IIlkesinin Rolü”, Eskişehir Osman Gazi Üniversitesi iiBF Dergisi, 9(3), Aralık, ss. 129-143.

Şenyüz, D., Yüce, M. \& Gerçek, A. (2018). Vergi Hukuku, 9. Baskı, Bursa, Ekin Basım Yayın Dağıtım. 